\title{
More scientific contact between East and West Germany?
}

\section{Munich}

GLASNOST has arrived at the East German Academy of Sciences. Despite the danger of scientists defecting, the East German Academy has agreed in principle to increase scientific exchange between the two Germanies.

Academy president Werner Scheler made an unprecedented visit to Bonn on 2 December to meet his counterpart in the Deutsche Forschungsgemeinschaft (DFG), president Hubert Markl. Scheler invited Markl to East Berlin in the spring of 1988 to sign a final agreement.

The DFG, which supports much of the basic research in West Germany, has 29 such agreements with countries all over the world, including most of Eastern Europe. For example, the Soviet Union has been sending researchers to West Germany since the early 1960 s, although the agreement between the DFG and the Soviet Academy of Sciences was signed only in 1970. All exchanges are financed out of the DFG budget except those with the Soviet Union, which the Research and Technology Ministry supports.

Scheler came to Bonn only after a threeyear delay in accepting the invitation of Markl's predecessor, Eugen Seibold. According to Eva-Maria Streier of the DFG, Scheler said he was able to visit only because of the current political thaw between East and West Germany. The East German delegation was uncharacteristically quick to accept the agreements between the DFG and other Eastern European countries as a basis for negotiating the new agreement. Even researchers in West Berlin may participate.

But large-scale exchange is unlikely, said Doris Schenk of the DFG, because of the risk that East German researchers might defect to West Germany. In the case of Soviet researchers, said Schenk, only 15-20 per cent of those specifically invited actually receive permission to visit West Germany.

Steven Dickman

\section{Basic research is threatened by West Germany's space plans}

Munich

FEAR has gripped the West German research community following the government's decision to participate in the three large projects of the European Space Agency (ESA).

In an unusually forceful statement, Heinz Staab, director of the Max Planck Gesellschaft (Max Planck Society or MPG), called upon the West German cabinet to finance its new space plans without damaging basic research. Staab said that there is "no sufficient scientific reason" to begin a European programme of manned space flight and that it is "absurd" to allow the financial pressures generated by the space programme and tax reform to reduce government support for basic research.

Staab's statement puts him on a collision course with Research and Technology Minister Heinz Riesenhuber. Riesenhuber has said that the three projects (the Hermes shuttle, the Columbus space station and the Ariane 5 launch vehicle) will cost West Germany DM500 million more a year than had been planned for the space programme. This money will come partly from the Research and Technology Ministry (BMFT) and partly from elsewhere in the West German budget.

BMFT will have about DM7,600 million at its disposal in 1988. The MPG accounts for about DM500 million of that, with the rest of its DM1,143 million bud- get (in 1987) coming from the Länder and private contributions.

Historically, West Germany's big science organizations - the MPG, the Deutsche Forschungsgemeinschaft (DFG), and the Westdeutschen Rektorenkonferenz - have held their own in budgetary conflicts with the government. In 1984, for example, the leaders of these three organizations wrote a letter to the government defending their budgets in the face of a similar challenge from the space programme. Their request for additional funds was granted.

Staab says that big projects begin to operate "under their own impetus" and that they are always "much more expensive than predicted". As West Germany had agreed to support the ESA projects for other than scientific reasons, Staab said that the research budget should not have to suffer. He added that there is sufficient justification for unmanned space missions (such as the X-ray satellite ROSAT), which are also much less expensive.

Staab's views were echoed in a more muted way by Hubert Markl, president of the DFG. Markl has been travelling tirelessly through West Germany this autumn, defending basic research to anyone who will listen. The DFG's budget was increased by 3 per cent for 1988 , which he says is far from sufficient.

Markl has called attention to the

\section{Superphénix not to rise from ashes yet}

Paris

THE French prototype 1,242-MW fast breeder reactor, Superphénix, at CreysMalville near Lyons, will not start up before mid-1988, according to reports from the Ministry of Industry. The reactor was shut down last June, following the discovery of a leak in a steel storage chamber containing liquid sodium (see Nature 328,$100 ; 1987$ ). When the chamber was drained, three 45$\mathrm{cm}$-long hairline fissures were found. The cause of the cracks has not yet been determined, but Electricité de France (EDF), which runs the reactor, argues that it could run safely for over a year without the defective chamber - which is used to store radioactive fuel on its way to and from the reactor core - while tests are carried out.

Industry Minister Alain Madelin, who is considering a confidential EDF report, expects that the reactor will nevertheless stay closed, at least until the middle of next year. Close to the Swiss border, the reactor has never been popular with France's neighbours, and restarting it without the chamber would be sure to bring howls of protest in a year of presidential elections. It is also not clear how fuel rods from the core would be stored in the event of a major accident.

Superphénix has already cost $£ 2,000$ million, making the electricity it produces 50 per cent more expensive than that from other French reactors. The prospect of a further bill of as much as $£ 40-£ 50$ million to repair or replace the storage chamber, putting the reactor out of action for perhaps three years, is a thorn in the side of Madelin, who, like his predecessors of both political colours, had hoped that Superphénix would be the first of a new generation of reactors in France.

The whole nuclear programme has slowed in France, since its peaks in 1977 and 1979 after the oil crisis. Instead of building one new reactor a year, as was the case from 1985 to 1987 - the last to open was at Nogent, near Paris, this year there will be one new reactor every two years.

Peter Coles

"mountain of scientists" resulting from the "mountain of students" that has filled West German universities to overflowing for the past decade. "It would be stupid for us to stop supporting them now", he said.

Markl added that the universities could use some of the thousands of millions of deutschmarks that are now being freed to stimulate the West German economy. "We shouldn't just spend that money for building highways", he said, but, rather, "we should make it available to universities for investments in equipment that they desperately need". Steven Dickman 